\title{
Potentiality of algae extracts in alleviating stresses effect on common bean under upper Egypt conditions
}

\author{
Noha Gamal Abu Setta1, Hani Saber ${ }^{*}$, Abu Bakr Abd El-Azim El-Dakkak ${ }^{2}$ and Hamdy Ramadan Galal ${ }^{1}$
}

${ }^{1}$ Botany and Microbiology Department, Faculty of Science, South Valley University, Qena, 83523, Egypt

2 Vegetable crop Departments, Horticulture research Institute, A. R. C., Giza, Egypt

Correspondence Author: Hani Saber ,Botany and Microbiology Department, Faculty of Science, South Valley University, Qena, 83523, Egypt

E-mail: hani.saber@sci.svu.edu.eg

Received date: 12 August 2018, Accepted date: 10 December 2018, Online date: 25 December 2018

Copyright: (C) 2018 N, G. Abu Setta et al., This is an open-access article distributed under the terms of the Creative Commons Attribution License, which permits unrestricted use, distribution, and reproduction in any medium, provided the original author and source are credited.

\begin{abstract}
Two laboratory and field experiments were carried out during the two successive seasons of 2016/2017 and 2017/2018 at Qena Faculty of Science, South Valley University, Qena Governorate, Egypt, and Shandaweel Research Station, Agriculture Research Center, Sohag Governorate, Egypt to study the chemical constituents of some micro and macro algae and effect of foliar spray with their extracts on growth and productivity of common bean plants under abiotic stress, i.e., cold stress; nitrogen deficiency or drought stress. Laboratory experiments proved that all used algae excrete plant growth promoting substances such as indole acetic acid (IAA), Gibberellic acid $\left(\mathrm{GA}_{3}\right.$ ) with excellence for Cystoseira myrica in (GA $\mathbf{m}_{3}$, while cyanobacteria were superior in indole acetic acid (IAA) that led to an increasing in common bean plant traits as a result of foliar spraying with these extracts that increment most studied bean characteristics over the control beside decreasing of stressful effects during cold planting season. These confirm that algalization spray by most studied algae extracts made as growth regulators considerably alleviate all stressful conditions. Several parameters were evaluated including growth criteria, photosynthetic pigments, yield and its components. The deleterious effect of stress was mitigated with different extents by these treatments. The beneficial effect of treatments was manifested in terms of enhanced growth and photosynthesis. These results reveal that the $0.4 \%$ of both Nostoc muscorum and Anabaena oryzae extracts can be considered the best extracts among the 8 algal extracts foliar spray treatments evaluated for all experimental conditions in the present work, i.e., cold, nitrogen deficiency or drought stresses. Moreover, both the $(0.4 \%$ Caulerpa racemosa) and $(0.4 \%$ Cystosiera myrica) extracts showed high positive responses only, in case of both cold and drought double stresses.
\end{abstract}

Key word: Algae, seaweed extracts, common bean, cold stress, drought stress, nitrogen deficiency.

\section{INTRODUCTION}

From time of the Aswan Dam has deprived the Nile Delta of the fertile silt previously brought by annual flooding; algalization could be of critical importance to the fertility of Egyptian fields [1]. There is now a greater interest in the marine organisms especially marine algae seeking agricultural fertility from natural products. Common beans (Phaseolus vulgaris L.) are one of the most important legumes in the Egyptian consumer and have been very successful in export markets. It is particularly susceptible and its poor adaptation to climatic stresses [2] can be partly explained by its long reproductive period, which can last between 25 and 35 days representing 35 to $45 \%$ of the total cycle length [3]. The effects of stress have a major economic influence since the bean is a food crop and a useful source of proteins. The ability of common bean to fix atmospheric nitrogen gives them an advantage when grown on soils low in nitrogen [4]. Common beans are poor fixers (less than $24 \mathrm{~kg}$ per feddan) and fix less than their nitrogen needs. Maximum economic yield for beans requires an additional 14.2- 23.6 $\mathrm{kg} / \mathrm{feddan}$ of fertilizer nitrogen. In the context of both the cost and environmental impact of chemical fertilizers, excessive dependence on chemical fertilizers is not so feasible a strategy in the long run. In this context, organic manures would be the practical option for farmers to increase productivity per unit area. Excessive dependence on chemical fertilizers has not only adversely affected the quality of human consumption and environment but also disturb the ecological balance. Biofertilizers can help solve the problem of feeding and increasing global population at a time when agriculture is facing various environmental stresses. It is important to understand the beneficial aspects of biofertilizers and implement its application to modern agricultural practices. The recent challenges to food production due to the increasing occurrence of biotic and abiotic stresses is likely due to climate change and will further reduce yields and/or will have an impact on crops in the $21^{\text {st }}$ century [5]. Hence, research into developing sustainable approaches to alleviate these stresses should be a priority.

God has created the seas, oceans and rivers and make them a source of many treasures and benefits that modern science is still discovering the benefits and secrets of this strange world and algae are one of the secrets of this wondrous world that must be used where it is semi-vegetarian living organisms. They are as diverse as wild plants, thus the harvest and collection it for use to benefit from them does not upset the natural biological balance of water.

More studies have shown that seaweed extracts protect plants against a number of biotic and abiotic stresses and offers potential for field application [6]. Further, seaweed extracts are considered an organic farm input as they are environmentally friendly and safe for the health of animals and humans. As a consequence of an 
Citation: Noha G. Abu Setta et al., Potentiality of algae extracts in alleviating stresses effect on common bean under upper Egypt conditions. Advances in Environmental Biology.12(12): 28-37. DOI:10.22587/aeb.2018.12.12.6

increasing demand for biodiversity in seeking organic fertilization for vegetable crops from natural products, there is now a greater interest in marine organisms, especially algae [7]. Many studies have revealed a wide range of beneficial effects of seaweed extract applications on plants [8], [9] and [10]. Drought, as an abiotic stress, affects plants at various levels of their organization include growth, plant structure, pigment content, tissue osmotic potential and the antioxidant defense mechanism and photosynthetic activity [11], [12] and [13]. Therefore, use of foliar application of algae and /or seaweeds extract may have become a new trend to reduce the harmful effects of drought on some crops. Although numerous studies have been carried out on the taxonomy, distribution, photochemistry and antibacterial activities of algae, little work has been done on the influence of their extracts on the growth of Phaseolus vulgaris grown under drought stress and /or nutrient deficiency.

The main objective of this study is to test: In vitro, Isolation and culturing of some algae samples, Processing the 4 Algal (micro and macro) extractions and determination some of chemical constituents of algal extractions. In vivo: Evaluation the foliar application effects of different concentrations of algal (micro and macro) extracts in enhancing the growth, yield and quality of Common bean (Phaseolus vulgaris) under abiotic stress, i.e., nitrogen deficiency and drought stress in open field under cold weather as applied experiments.

\section{MATERIALS AND METHODS}

Laboratory and field experiments were carried out during the two successive seasons of 2016/2017 and 2017/2018 at Qena Fac. Sci., South Valley Univ., Qena Governorate, Egypt, and Shandaweel Res. Station, Agric. Res. Center, Sohag Governorate, Egypt to study the chemical constituents of some micro and macro algae and effect of foliar spray with their extracts on growth and productivity of common bean plants cultivated in clay loamy soil under abiotic stress. Common bean (Phaseolus vulgaris L.) seeds, i.e. cv. Paulista were obtained from the Self-pollination Vegetable Research Department, Horticulture Research Institute, Agric. Res. Center, Giza.

Macroalgae sources and collection sites characterizations:

Both green (Caulerpa sp) and brown (Cystoseira sp) marine seaweeds were collected; on May 2016; from two localities along the Red Sea coast at Hurghada and Safaga, respectively, Egypt. The collection sites are at $\mathrm{km} 8$ south Hurghada (latitude $27^{\circ} 12^{\prime} \mathrm{N} \&$ longitude $33^{\circ} 50^{\prime} E$ ) and $\mathrm{km} 17 \mathrm{south}$ Safaga (latitude $26^{\circ} 46^{\prime} \mathrm{N} \&$ longitude $33^{\circ} 56^{\prime} E$ ). Algal samples were handpicked, washed thoroughly with seawater to remove all the impurities, sand particles and epiphytes. They were transported in an icebox to the phycology laboratory, identified with the help of the Botany and Microbiology Department "Phycology Research Laboratory", Qena Faculty of Science, South Valley University as Caulerpa racemosa (green algae) and Cystoseira myrica (brown algae). Samples were washed thoroughly using tap water and then with sterile distilled water to be air dried at room temperature for 1 week. Each tested alga was transformed to a powder form using a blender.

Cyanobacterial strains and culture preparation:

$\mathrm{N}_{2}$-fixing (Nostoc muscorum and Anabaena oryzae) cyanobacteria strains were obtained from Microbiology Department, Soils, Water and Environment Res. Inst., Agric. Res. Center, Giza, Egypt. The cyanobacterial strains were grown separately on the nitrogen free medium BG11 [14]. Ten ml citric acid stock solution (0.06 $\mathrm{g} / 100 \mathrm{ml}), 1 \mathrm{ml}$ EDTA $(1 \mathrm{mg} / \mathrm{ml})$ and $1 \mathrm{ml}$ trace metal mix adjusted to $\mathrm{pH} 7.4$ were added and the total volume was made up to one liter. The cultures were incubated in growth chamber under daylight fluorescent lamps $\left(300 \mu \mathrm{mol} \mathrm{m}{ }^{-2} \mathrm{~s}^{-1}\right)$ at ambient temperature $\left(30 \pm 2^{\circ} \mathrm{C}\right)$ for both strains. The cells in the exponential phase of growth (15 days after culture) were harvested by means of filtration and subsequently dried for $72 \mathrm{~h}$. The dried cells were ground to powder and extracted with $70 \%$ ethanol.

Extracts preparation:

The ethanolic extraction was carried out by adding $30 \mathrm{ml}$ of ethanol (70\%) to $10 \mathrm{gm}$ of dried fine powder algae (each species, separately), shaken 10 mins and allowed to stand for 15 mins. The extract was then filtered using whatman filter paper No4. The extract was concentrated under low pressure at $40{ }^{\circ} \mathrm{C}$, then the extract (100\% concentrate) was kept under $-4{ }^{\circ} \mathrm{C}$ till use in the following experiments.

\section{Experimental parameters:}

The four algal species were analyzed for their contents of photosynthetic pigments (chlorophyll a and carotenoids), Flavonoids (mg/100gm), Total phenols (mg/100gm), Anti-oxidant (\%), Total sugar (\%), Total protein (\%), Total free amino acid (g/100g), Proline (mg/100gm), and for total N (\%), total P (\%), total K (\%) and plant growth hormones. The contents of photosynthetic pigments were extracted and measured by spectrophotometric methods [15] and [16]. The total flavonoid contents of the algal extract were estimated according to the method described by Bag et al., [17], total phenol was determined by Folin-Ciocalteu method [18], the total antioxidant was eluted by using the method described by Prieto et al [19]. The total sugars of the powdered algae were estimated by method of [20] using High Performance Liquid Chromatography (HPLC) apparatus, Protein content was determined as Lowry et al [21] method, determination of the free amino acids was carried out according to Sadasivam and Manickam [22] and Proline was determined by a modification of the method of [23]. Contents of total N $(\%), \mathrm{P}(\%)$ and $\mathrm{K}(\%)$ were estimated as reported by Allen et al. [24] and analyzed by using GBC.932 Atomic Absorption Spectrophotometer (AAS). The separation of plant growth hormones in the four algal species were carried out according to [25] and determined by HPLC. The obtained results were statistically analyzed to determine the degree of significance between the different algae genera. Results are presented as mean of three replicates \pm standard error.

\section{Open field:}

Treatments and Experimental Layout:

The concentrations of $0.0,0.3$ and $0.4 \%$ from each of the four micro and macro algae $70 \%$ ethanolic extractions were applied as foliar spray on common bean plants in two field experiments i.e., nitrogen deficiency and drought stress at the winter season of 2017/2018. The treatments of the two experiments were applied as following:

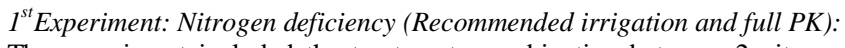

The experiment included the treatments combination between 2 nitrogen rates, four algal species extracts and three concentrations as: a): foliar spray with separately extraction of four algal species at both $(0.3 \%$, and $0.4 \%)$ rates as well as distilled water treatment $(0.0 \%$ alga) with Nitrogen deficiency (half of the recommended dose of nitrogen fertilizer, in 9 treatments). b): foliar spray with separately extraction of four algal species at both $(0.3 \%$, and $0.4 \%)$ rates as well as distilled water treatment $(0.0 \%$ alga) with nitrogen fertilization at the full $(100 \%)$ recommended dose in 9 treatments.

\section{$2^{\text {nd }}$ Experiment: Drought Stress (Full NPK):}

Also, the experiment included the same above algal species extracts and concentrations applied in the $1^{\text {st }}$ experiment combined with the 2 irrigation regimes treatments as: The first irrigation regime was drought stress (DS), in which the plants were irrigated up to the end of the vegetative stage (on 28 $8^{\text {th }}$ December 2017) and thereafter the irrigation was halted until physiological maturity, thus exposing the plants to terminal drought stress (Stressing was done for about 45 days). Normal irrigation resumed after pod filling stage. The second irrigation regime was non-stress (NS), in which the plants were normally irrigated. The treatments were arranged in split plot system. Nitrogen ( $1^{\text {st }}$ exp.) and irrigation $\left(2^{\text {nd }}\right.$ exp.) treatments were assigned at random in the main plots of $1^{\text {st }}$ and $2^{\text {nd }}$ experiments, respectively while sub plots were devoted to algal extracts in the different concentrations in both experiments. The physical and chemical analyses of the experimental soil are presented in Table (1). Local meteorological data at Shandaweel region during winter season of 2017-2018 were given in Fig.1. 
Citation: Noha G. Abu Setta et al., Potentiality of algae extracts in alleviating stresses effect on common bean under upper Egypt conditions. Advances in Environmental Biology.12(12): 28-37. DOI:10.22587/aeb.2018.12.12.6

All treatments were randomly arranged in a randomized complete blocks design with three replicates in the site of the experiment (Shandaweel Agric. Res. Station, Sohag Governorate, Egypt - latitude $26.33 \mathrm{~N}$ \& longitude 31.42 E and Elevation 61 meters from the sea level). The area of the experimental unit was $10.8 \mathrm{~m}^{2} ;$ it contained six rows of each $3 \mathrm{~m}$ length and $0.6 \mathrm{~m}$ width. The distance between plants was $7 \mathrm{~cm}$. Plants were sprayed 3 times with different assigned treatments; the first one was at 25 days after sowing and repeated each 10 days intervals. Seeds were sown in $22^{\text {nd }}$ of November (relatively cold weather). All plots of both experiments received equal amounts of mineral $\mathrm{P}$ and $\mathrm{K}$ fertilizers which used by common bean plants in clay loam soil at 200 and $100 \mathrm{~kg} / \mathrm{fed}$, respectively in the form of calcium superphosphate $\left(15.5 \% \mathrm{P}_{2} \mathrm{O}_{5}\right)$ and potassium sulphate $\left(48 \% \mathrm{~K}_{2} \mathrm{O}\right)$, respectively. While, only the nine of $100 \% \mathrm{~N}$ treatments in the $1^{\text {st }}$ experiment and all the treatments of the $2^{\text {nd }}$ one was received the recommended dose $(200 \mathrm{~kg} / \mathrm{fed})$ of nitrogen as ammonium sulfate $(20.5 \% \mathrm{~N})$. The other normal agricultural treatments such as weeding, pest and insect control were practiced as recommended for the conventional common bean planting.

Table (1): Soil physical and chemical analyses before common bean cultivation at the applied experimental site.

\begin{tabular}{|c|c|c|c|}
\hline \multirow[t]{2}{*}{ Physical properties } & \multicolumn{2}{|l|}{ Organic matter $(\%)$} & 0.98 \\
\hline & \multicolumn{2}{|l|}{ Textural class } & Clay loam \\
\hline \multicolumn{4}{|l|}{ Chemical properties } \\
\hline & 7.9 \\
\hline \multicolumn{3}{|l|}{ Electric conductivity E.C. $(\mathrm{ds} / \mathrm{m})$} & 0.62 \\
\hline \multirow{7}{*}{ Available nutrients (ppm) } & \multirow[t]{3}{*}{ Macro-elements } & $\mathrm{N}$ & 24 \\
\hline & & $\mathrm{P}$ & 16 \\
\hline & & $\mathrm{K}$ & 298 \\
\hline & \multirow[t]{4}{*}{ Micro-elements } & $\mathrm{Zn}$ & 0.39 \\
\hline & & $\mathrm{Mn}$ & 1.44 \\
\hline & & $\mathrm{Fe}$ & 1.09 \\
\hline & & $\mathbf{C u}$ & 0.59 \\
\hline
\end{tabular}

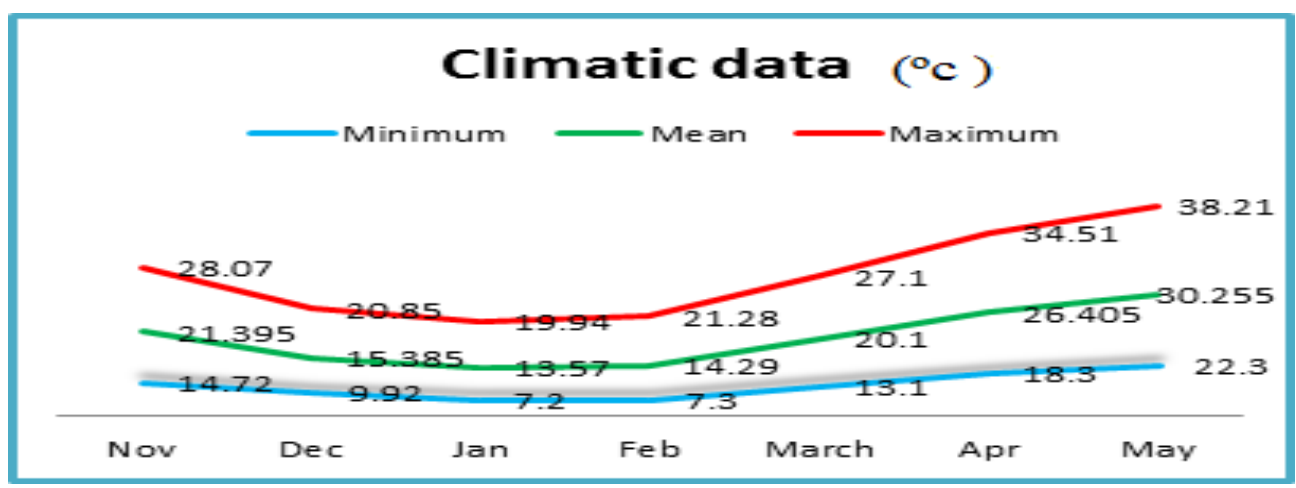

Fig.1: The local meteorological data during the winter season prevailing at the region of common bean cultivation.

Experimental parameters:1) Vegetative growth characteristics:

Each of Plant height $(\mathrm{cm})$, number of leaves, total leaf area $\left(\mathrm{cm}^{2}\right) /$ plant (using the method of determining the weight of unit area of leaves) and number of branches/plant characteristics of common bean (Phaseolus vulgaris L.) plants at 65 days after sowing were measured and calculated. Ten plants from each treatment were randomly taken for measurements.

2) Photosynthetic pigments:

Chlorophyll a\&b in the common bean leaves were determine calorimetrically at 65 days after sowing according to the methods described by [26] and calculated as $\mathrm{mg} / \mathrm{g}$ fresh weight. Also, total leaf chlorophyll content measured by SPAD chlorophyll meter reading (SCMR) at mid-pod filling stage on 10 fully expanded young leaves of three plants in each plot using a non-destructive, portable SPAD-502 chlorophyll meter (Minolta Camera Co., Ltd., Japan).

3) Yield and yield components:

At harvest time, i.e. 100 days after sowing ten plants were randomly chosen from each plot to measure and /or count pod and yield characteristics, i.e. pod length, pod width, pod weight (g), number of seeds/pods, number of pods/plants, individual plant yield (g) and total pod yield per feddan (tons / fed).

Statistical analysis:

All data were statistically analyzed applying analysis of variance (ANOVA) according to [27] by ASSISTAT Version 7.7 en (2017) - UFCG-Brazil [28] and [29]. The means of chosen parameters were compared employing the LSD test at the significance level of $\mathrm{p}=0.05$.

\section{RESULTS AND DISCUSSION}

Determination of some metabolites in the studied algae:

Crude yield and chemical constituents of the four studied micro and macro algae extracts are shown in Table 3. The results in Table 3 show that yield of about $7.3947 \mathrm{~g}(24.649 \%)$ was obtained from the ethanolic extract of Nostoc muscorum, followed by Caulerpa racemosa, Anabaena oryzae and Cystoseira myrica extracts, which yielded 6.1707, 5.5416 and $2.8497 \mathrm{~g}$ in descending order.

Table 3: Extraction yield of crude extract (\% dry weight)

\begin{tabular}{|l|l|l|l|}
\hline Alga name & Extract Wt $(\mathbf{g})$ & Sample Wt $(\mathrm{g})$ & \% Yield \\
\hline Anabaena oryzae & $5.5416 \pm 0.0002^{*}$ & 30 & 18.472 \\
\hline Nostoc muscorum & $7.3947 \pm 0.00016$ & 30 & 24.649 \\
\hline Caulerpa racemosa & $6.1707 \pm 0.0094$ & 30 & 20.569 \\
\hline Cystoseira myrica & $2.8497 \pm 0.0005$ & 30 & 9.499 \\
\hline
\end{tabular}

${ }^{*}$ Mean values \pm Standard Error 
It was clearly, noticed that there were significant differences among the 4 studied algae genera in terms of antioxidant, polyphenols, total flavonoid, protein, chlorophyll a, carotenoid and K element contents. On the opposite, no significant differences were observed between Caulerpa racemosa and Cystoseira myrica seaweed extracts in total sugar, $\mathrm{N}$ element, proline and total free amino acid as well as between Caulerpa racemosa (macro green alga) and Nostoc muscorum (micro blue green alga) in P \% element. As shown in Fig. $2_{a \& b}$; the total antioxidant was significantly different between the four studied algae extracts with high values arranged as Nostoc muscorum (8.76\%), Caulerpa racemosa (13.66\%), Cystoseira myrica (14.52\%) and Anabaena oryzae (15.03\%) extracts in ascending order. It is appearing that the total antioxidant values of ethanol extracts of the tested algae are nearly the same.
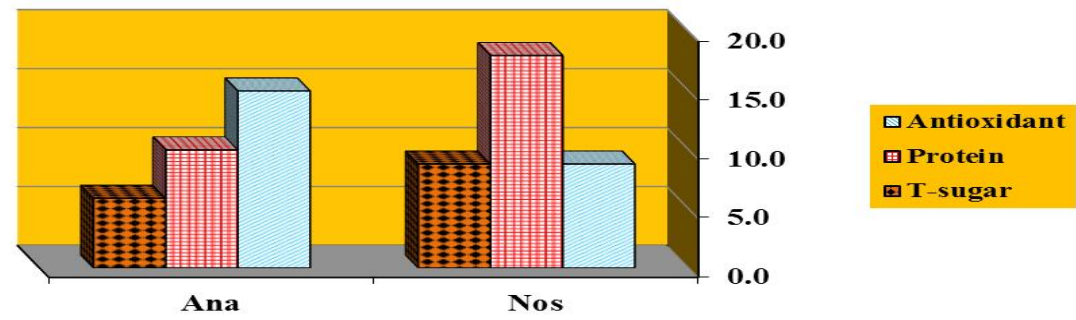

Ana

Nos

Fig. 2a: The percentage of anti-oxidant, protein and total sugar constituents of the two micro-algae extracts.

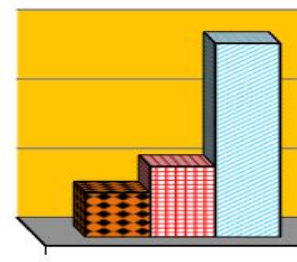

Cau

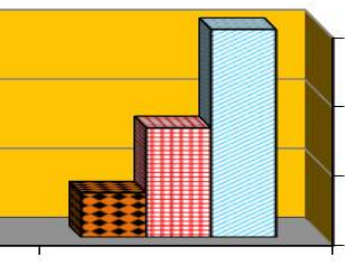

Cys
15.0

10.0

5.0

o.o

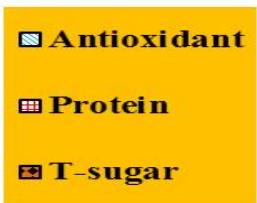

T-sugar

Fig. 2b: The percentage of anti-oxidant, protein and total sugar constituents of the two macro- algae extracts.

Our results reveal that the ethanolic extracts of the four studied algae found to have good antioxidant. These results are confirmed by those observed by Viswanathan et al. [30] and Soad and Amani [31]. Moreover, in our study, the algal extracts of both Anabaena oryzae and Cystoseira myrica showed as a noticeable protective natural anti-oxidants as showed in Fig.2a\&b.

Polyphenols in Algal Extracts:

Polyphenols constitute a heterogeneous group of molecules which provide a wide range of potential biological activity [32], which includes phenolic acids, lignins, flavonoids, tocopherols, and tannins. Total phenol and flavonoid contents of selected species of algae are presented in Fig. 3 . The highest total phenol and flavonoid contents were $62 \mathrm{mg} / 100 \mathrm{~g}$ and $0.249 \mathrm{mg} / 100 \mathrm{~g}$, respectively, as recorded in Anabaena oryzae and the lowest contents were $11 \mathrm{mg} / 100 \mathrm{~g}$ and 0.046 $\mathrm{mg} / 100 \mathrm{~g}$, respectively, as recorded in Caulerpa racemosa.

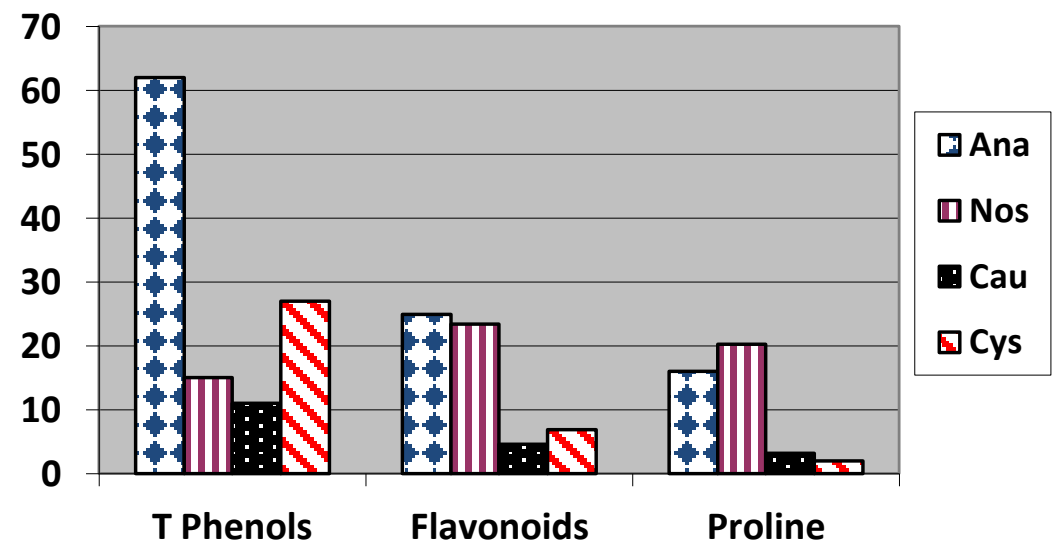

Fig.3.: Total phenols, flavonoids and proline $(\mathrm{mg} / 100 \mathrm{~g})$ of the four studied algae extracts.

Accordingly, the present study was promising, as algae polyphenolic compounds are effective antioxidants. Total flavonoids in the studied algae ranged from 0.046 to $0.249 \mathrm{mg} / 100 \mathrm{~g}$. It has been reported that the presence of phyto-constituents such as flavonoids and polyphenols prevent a number of diseases through their free radical scavenging activity [33] and these phenolic compounds, which include phenol and flavonoids, have been found in appreciable amounts in the four studied algae. Due to their broad spectrum of chemical and biological activities, including antioxidant and free radical scavenging properties, Kahkonen et al. [34] stated that flavonoids are probably the most important natural phenol. On the other hand, Burtin [32] and L'opez et al [35] concluded that seaweeds have been shown as a rich source of different types of polyphenols with unique structural properties and the highest contents of these compounds are found in brown seaweeds. In our investigation, we found out that the ethanolic extract of Anabaena oryzae contained higher concentrations of total phenols (62mg/100g), (Fig.3) followed by Cystoseira myrica (Brown algae). These results overlap with those reported by Tierney et al. (2013) [36]. Data show that the contents of total protein (Fig.2 $2_{a \& b}$ ), total sugars (Fig. $2_{\text {a\&b }}$ ), proline (Fig.3), carotenoid (Fig.5), total N content (Fig.6) and total free amino acids (Fig.7) were higher in cyanobacterial (blue green algae) species, Nostoc muscorum and Anabaena oryzae than in both marine algae, brown seaweed Cystoseira myrica or green seaweed Caulerpa racemosa; the opposite was achieved for the contents of total K (Fig.6). 
Citation: Noha G. Abu Setta et al., Potentiality of algae extracts in alleviating stresses effect on common bean under upper Egypt conditions. Advances in Environmental Biology.12(12): 28-37. DOI:10.22587/aeb.2018.12.12.6

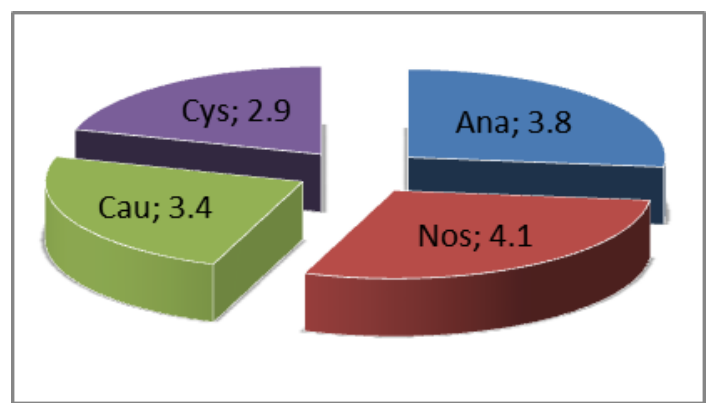

Fig.4: Chlorophyll $(\mu \mathrm{g} / \mathrm{ml})$ of the four studied algae extracts.

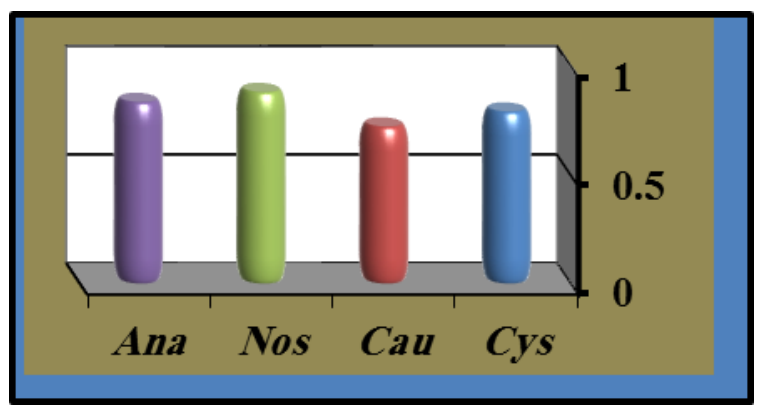

Fig.5: Carotenoids $(\mu \mathrm{g} / \mathrm{ml})$ of the four studied algae extracts.

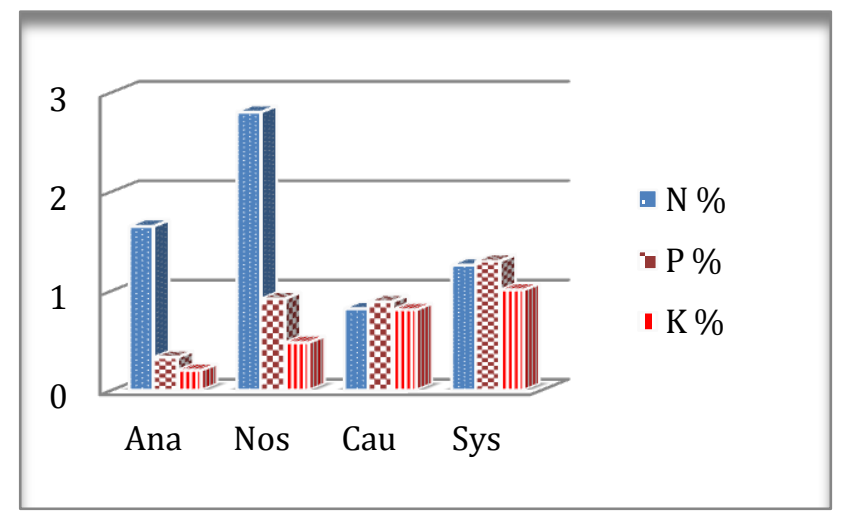

Fig. 6: Nitrogen (N), Phosphor (P) and potassium (K) \% of the four studied algae extracts.

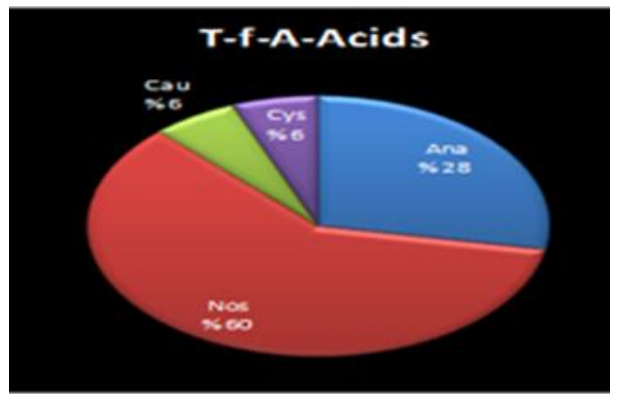

Fig. 7: Total free amino acids $(\mathrm{g} / 100 \mathrm{~g})$ of the four studied algae extracts

Chlorophyll a content (Fig.4) was significantly different between the four studied algae extracts with values arranged as $2.921 \mu \mathrm{g} / \mathrm{ml}$ (Cystoseira myrica), $3.841 \mu \mathrm{g} / \mathrm{ml}$ (Anabaena oryzae), $4.137 \mu \mathrm{g} / \mathrm{ml}$ (Nostoc muscorum) and $4.430 \mu \mathrm{g} / \mathrm{ml}$ (Caulerpa racemosa). Carotenoids serve as precursors of signaling molecules that influence plant development and biotic/abiotic stress responses [37]. As shown in Fig. 6, the total P was significantly different between the four studied algae extracts with values ranged from $0.33 \%$ in the ethanolic extract of the blue green alga Anabaena oryzae to $1.34 \%$ in the brown seaweed Cystoseira myrica extracts and arranged as Anabaena oryzae (0.33\%), Caulerpa racemosa ( $0.88 \%)$, Nostoc muscorum $(0.92 \%)$ and Cystoseira myrica $(1.34 \%)$ extracts in ascending order. Accordingly, within the two cyanobacterial species, Nostoc muscorum extract recoded the best results regarding all abovementioned studied components compared to Anabaena oryzae extract except Anti-oxidant (Fig.2 ${ }_{a}$ ), flavonoids (Fig.3), total phenols (Fig.3) and carotenoid (Fig.5) in which Anabaena oryzae have the highest values. Also, within the two macro-algae species, Caulerpa racemosa extract exhibited higher contents in only 4 out of the 12 studied constituents, i.e. total sugars (Fig 2 ${ }_{b}$ ), proline (Fig.3) and chlorophyll a (Fig.4) than Cystoseira myrica extract which have the highest levels in the all remain components. [38] demonstrated that the protein content of brown seaweeds is generally small (average: 5-15\% of the dry weight), whereas higher protein contents are recorded in the green and red seaweeds (on average 10-30\% of the dry weight) and the ethanolic extract of the alga Cystoseira compressa proved to have an anti-oxidants effect using protein sulfhydryl groups. As shown in Fig.8, both micro and macro algae showed higher contents of growth promoting substances than the growth inhibitory phytohormones (determined as abscisic acid). 
Citation: Noha G. Abu Setta et al., Potentiality of algae extracts in alleviating stresses effect on common bean under upper Egypt conditions. Advances in Environmental Biology.12(12): 28-37. DOI:10.22587/aeb.2018.12.12.6

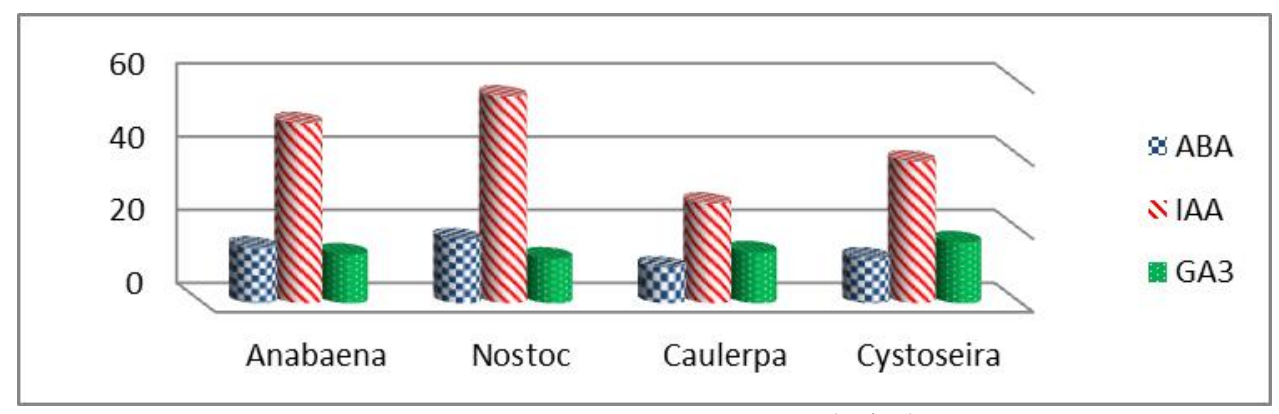

Fig.8: ABA, IAA, $\mathrm{GA}_{3}$ for algae species $(\mu \mathrm{g} / \mathrm{gm})$

Also, the two micro algae (cyanobacterial species) showed higher levels of indole acetic acid (IAA) and abscisic acid (ABA) than the two macro (green and brown algae) species, whereas the letters contained higher gibberellic acid $\left(\mathrm{GA}_{3}\right)$ content than the formers. Generally, our results proved that all used algae excrete plant growth promoting substances such as indole acetic acid (IAA), Gibberellic acid $\left(\mathrm{GA}_{3}\right)$ with excellence for Cystoseira myrica in $\mathrm{GA}_{3}$, while cyanobacteria were superior in indole acetic acid (IAA).

Open field trials:

Two applied experiments, under cold stress combined with nitrogen deficiency or drought stress, were carried out in the open field to study and evaluate the potentiality of various concentrations of four micro and macro algae extracts namely: Anabaena oryzae, Nostoc muscorum, Caulerpa racemosa and Cystoseira myrica and their role in alleviating the injurious effect of stresses on Phaseolus vulgaris plants in Upper Egypt (Sohag governorate) region.

\begin{tabular}{|c|c|c|c|c|c|}
\hline \multicolumn{2}{|c|}{$\begin{array}{l}\text { Characters } \\
\text { Algae Extract foliar spray }\end{array}$} & \multirow{2}{*}{$\begin{array}{c}\text { Plant height (cm) } \\
39.00\end{array}$} & \multirow{2}{*}{$\begin{array}{c}\begin{array}{c}\text { No. of } \\
\text { Leaves per plant }\end{array} \\
17.3 \\
\end{array}$} & \multirow{2}{*}{$\begin{array}{c}\begin{array}{c}\text { No. of } \\
\text { Branches per plant }\end{array} \\
3.7 \\
\end{array}$} & \multirow{2}{*}{$\begin{array}{c}\text { Leaf area }\left(\mathbf{c m}^{2}\right) \\
953.80\end{array}$} \\
\hline DW & $(\mathbf{0 . 0} \%)$ & & & & \\
\hline \multirow[t]{2}{*}{ Ana } & $(\mathbf{0 . 3} \%)$ & 41.33 & 12.3 & 5.0 & 1037.07 \\
\hline & $(0.4 \%)$ & 46.00 & 13.7 & 5.3 & 1137.73 \\
\hline \multirow[t]{2}{*}{ Nos } & $(0.3 \%)$ & 42.67 & 12.3 & 6.7 & 1142.27 \\
\hline & $(0.4 \%)$ & 45.67 & 18.0 & 6.0 & 1159.60 \\
\hline \multirow[t]{2}{*}{ Cau } & $(0.3 \%)$ & 48.33 & 16.3 & 5.7 & 1147.47 \\
\hline & $(0.4 \%)$ & 48.67 & 19.0 & 6.7 & 1147.07 \\
\hline \multirow[t]{2}{*}{ Cys } & $(0.3 \%)$ & 45.00 & 17.3 & 5.3 & 1159.53 \\
\hline & $(\mathbf{0 . 4} \%)$ & 49.00 & 17.7 & 5.3 & 1115.47 \\
\hline \multicolumn{2}{|c|}{ L.S.D at 0.05} & 1.94 & 2.18 & 1.72 & 69.08 \\
\hline
\end{tabular}

$50 \% \mathrm{~N}=$ nitrogen deficiency $(50 \%$ of recommended dose) $100 \% \mathrm{~N}=$ nitrogen recommended $(100 \%)$ dose

Ana: Anabaena oryzae Nos : Nostoc muscorum Cau : Caulerpa racemosa Cys : Cystoseira myrica DW: distilled water (without algae)

Changes in vegetative growth traits as affected by foliar spray of algae extracts on the common bean plants grown under cold stress condition (winter season) presented in Table $4_{\mathrm{a} \& b}$. As regard to the effect of algal foliar spray along with recommended nitrogen treatment (100\% $\mathrm{N}$ ) in which the plants were under cold temperature conditions, the results showed that, increase in growth rate such as plant height, number of both leaves and branches per plant as well as leaf area (comparing to distilled water) was obtained as a result of most different treatments in this study. Treated plants with the different concentrations of algae extracts showed that $0.4 \%$ of Caulerpa racemosa extracts exhibited a high significant increment in all vegetative growth traits, i.e., number of branches per plant, plant height, leaf area and number of leaves per plant by $81.1 \%, 24.8 \%, 20.3 \%$ and $9.8 \%$, in descending order, over the corresponding untreated plants (control) followed by Nostoc in most traits.

Table $4_{\mathrm{b}}$ : Changes $\%$ in vegetative growth traits as affected by foliar spray of algae extracts on the common bean plants grown under cold stress condition

\begin{tabular}{|c|c|c|c|c|c|c|c|}
\hline \multicolumn{2}{|c|}{ Treatments } & \multicolumn{2}{|c|}{ Micro algae extraction } & \multicolumn{2}{|c|}{ Macro algae extraction } & \multirow{2}{*}{$\begin{array}{c}\text { Range }^{\dagger} \\
\%\end{array}$} & \multirow{2}{*}{ No. } \\
\hline Traits & $\frac{\text { Conc. }}{\%}$ & $\begin{array}{c}\text { Anabaena } \\
\text { Orvzae }\end{array}$ & $\begin{array}{c}\text { Nostoc } \\
\text { muscorum }\end{array}$ & $\begin{array}{l}\text { Caulerpa } \\
\text { racemosa }\end{array}$ & $\begin{array}{c}\text { Cystoseira } \\
\text { myrica }\end{array}$ & & \\
\hline \multirow{3}{*}{ plant height } & 0 & $100 \%$ & $100 \%$ & $100 \%$ & $100 \%$ & - & - \\
\hline & 0.3 & 105.97 & 109.41 & 123.92 & 115.38 & $6.0-23.9$ & 4 \\
\hline & 0.4 & 117.95 & 117.10 & 124.79 & 125.64 & $17.1-25.6$ & 4 \\
\hline \multirow{3}{*}{ No of leaves } & 0 & $100 \%$ & $100 \%$ & $100 \%$ & $100 \%$ & - & - \\
\hline & 0.3 & 71.10 & 71.10 & 94.22 & 100.00 & $\begin{array}{c}(-28.9)- \\
\text { equal }\end{array}$ & - \\
\hline & 0.4 & 79.19 & 104.05 & 109.83 & 102.31 & $(-20.8)-9.8$ & - \\
\hline \multirow{3}{*}{ No of branches } & 0 & $100 \%$ & $100 \%$ & $100 \%$ & $100 \%$ & - & - \\
\hline & 0.3 & 135.1 & 181.1 & 154.1 & 143.2 & $35.1-81.1$ & 2 \\
\hline & 0.4 & 143.2 & 162.2 & 181.1 & 143.2 & $43.2-81.1$ & 2 \\
\hline \multirow{3}{*}{ Leaf area } & 0 & $100 \%$ & $100 \%$ & $100 \%$ & $100 \%$ & - & - \\
\hline & 0.3 & 108.73 & 119.76 & 120.31 & 121.57 & $8.7-21.6$ & 4 \\
\hline & 0.4 & 119.28 & 121.58 & 120.27 & 116.95 & $17.0-21.6$ & 4 \\
\hline
\end{tabular}

Range of increment \% within the same concentration in all extracts over control ${ }^{*}$ No. of superior extracts, on the base of the desirable significant effect

The extent of increment variation for plant height was from about $6.0 \%-25.6 \%$ for all types and concentration of extracts (Table $4 \mathrm{a \& b}$ ); with 8 extracts showing a significant positive effect. The responses expression for increasing number of leaves per plant varied with values ranging from $-28.9 \%-9.8 \%$ for all types of extracts with insignificant positive increment or significantly effects in all extracts except both $0.3 \%$ and $0.4 \%$ Anabaena oryzae as well as $0.3 \%$ Nostoc muscorum extracts which have significant decrease effects on number of leaves/plant. Significant increment up to $81.1 \%$ over control was recorded for branches/plant with our extracts exhibited significantly increasing over distilled water control. For leaf area, the extent of variation was from $8.7 \%-21.6 \%$ for all types of application (Table $4_{b}$ ) with 8 extracts showing positive increment effect. 
Citation: Noha G. Abu Setta et al., Potentiality of algae extracts in alleviating stresses effect on common bean under upper Egypt conditions. Advances in Environmental Biology.12(12): 28-37. DOI:10.22587/aeb.2018.12.12.6

Photosynthetic pigments:

Results showed that, increase in photosynthetic pigments such as chlorophyll a, chlorophyll b and total chlorophyll under cold temperature conditions (comparing to distilled water) was obtained as a result of most different treatments in this study.

Table 5: Changes in pigments content traits as affected by foliar spray of algae extracts on the common bean plants grown under cold stress condition.

\begin{tabular}{|c|c|c|c|c|c|c|c|}
\hline \multicolumn{2}{|c|}{ Treatments } & \multicolumn{2}{|c|}{ Micro algae extraction } & \multicolumn{2}{|c|}{ Macro algae extraction } & \multirow[t]{3}{*}{ Range $^{\dagger}$} & \multirow[t]{3}{*}{ No. } \\
\hline \multirow[t]{2}{*}{ N-levels } & Conc. & Anabaena & Nostoc & Caulerpa & Cystoseira & & \\
\hline & $\%$ & Oryzae & muscorum & racemosa & myrica & & \\
\hline \multirow[t]{3}{*}{ Chl.-a } & 0 & $100 \%$ & $100 \%$ & $100 \%$ & $100 \%$ & - & \\
\hline & 0.3 & 98.64 & 87.07 & 82.31 & 95.92 & $(-17.7)-(-1.4)$ & - \\
\hline & 0.4 & 108.16 & 108.16 & 111.56 & 116.33 & $8.2-16.3$ & - \\
\hline \multirow[t]{3}{*}{ Chl.-b } & 0 & $100 \%$ & $100 \%$ & $100 \%$ & $100 \%$ & - & \\
\hline & 0.3 & 98.33 & 90.00 & 85.00 & 98.33 & $(-15.0)-(-1.7)$ & \\
\hline & 0.4 & 113.33 & 108.33 & 113.33 & 121.67 & $8.3-21.7$ & 1 \\
\hline \multirow[t]{3}{*}{ Total Chl. } & 0 & $100 \%$ & $100 \%$ & $100 \%$ & $100 \%$ & - & - \\
\hline & 0.3 & 98.53 & 87.01 & 82.84 & 96.08 & $(-17.2)-(-1.5)$ & - \\
\hline & 0.4 & 108.58 & 108.33 & 111.52 & 116.67 & $8.3-6.7$ & - \\
\hline
\end{tabular}

Range of increment $\%$ within the same concentration in all extracts over control.

No. of superior extracts, on the base of the desirable significant effect.

Treated plants with the different concentrations of algae species (Table 5) showed that, $0.4 \%$ Cystoseira myrica extract showed a maximum increment in chlorophyll a, chlorophyll b and total chlorophyll by $16.3 \%, 21.7 \%$ and $16.7 \%$, respectively over the corresponding untreated plants (control) followed by $0.4 \%$ conc. of Caulerpa racemosa and both blue green algae i.e. Anbaena oryzae and Nostoc muscorum. On the other hand, low concentration (0. $3 \%$ ) of all algae species extracts exhibited slightly decrease effects in pigments content. On the other hand, only one alga extract showed significant increment on chlorophyll-b while none of the extracts showed significant effect for both chlorophyll-a or total chlorophyll traits.

Table 6: Changes in pod and yield traits as affected by foliar spray of algae extracts on the common bean plants grown under cold stress condition

\begin{tabular}{|c|c|c|c|c|c|c|c|}
\hline \multicolumn{2}{|c|}{ Treatments } & \multicolumn{2}{|c|}{ Micro algae extraction } & \multicolumn{2}{|c|}{ Macro algae extraction } & \multirow[t]{2}{*}{ Range $^{\dagger}$} & \multirow[t]{2}{*}{ No. } \\
\hline Trait & $\begin{array}{c}\text { Conc. } \\
\%\end{array}$ & $\begin{array}{c}\text { Anabaena } \\
\text { oryzae }\end{array}$ & $\begin{array}{c}\text { Nostoc } \\
\text { muscorum }\end{array}$ & $\begin{array}{l}\text { Caulerpa } \\
\text { racemose }\end{array}$ & $\begin{array}{c}\text { Cystoseira } \\
\text { myrica }\end{array}$ & & \\
\hline \multirow[t]{3}{*}{ Pod length } & 0 & $100 \%$ & $100 \%$ & $100 \%$ & $100 \%$ & - & - \\
\hline & 0.3 & 111.02 & 106.78 & 105.08 & 104.24 & $5.1-11.0$ & - \\
\hline & 0.4 & 105.93 & 102.54 & 90.68 & 104.24 & $-9.3-5.9$ & - \\
\hline \multirow[t]{3}{*}{ No seeds } & 0 & $100 \%$ & $100 \%$ & $100 \%$ & $100 \%$ & - & - \\
\hline & 0.3 & 133.25 & 133.25 & 125.00 & 125.00 & $25-33.3$ & - \\
\hline & 0.4 & 125.00 & 108.25 & 91.75 & 133.25 & $-8.3-33.3$ & - \\
\hline \multirow[t]{3}{*}{ Pod weight } & 0 & $100 \%$ & $100 \%$ & $100 \%$ & $100 \%$ & - & - \\
\hline & 0.3 & 144.70 & 130.98 & 110.81 & 119.96 & $10.8-44.7$ & 2 \\
\hline & 0.4 & 142.41 & 151.1 & 98.34 & 117.05 & $-1.7-51.1$ & 2 \\
\hline \multirow[t]{3}{*}{ Pods No } & 0 & $100 \%$ & $100 \%$ & $100 \%$ & $100 \%$ & - & - \\
\hline & 0.3 & 100 & 126.93 & 115.39 & 134.62 & Equal - 34.6 & 6 \\
\hline & 0.4 & 125.00 & 146.15 & 150.00 & 157.69 & $25.0-57.7$ & 4 \\
\hline \multirow[t]{3}{*}{ Yield } & 0 & $100 \%$ & $100 \%$ & $100 \%$ & $100 \%$ & - & - \\
\hline & 0.3 & 156.91 & 186.18 & 143.50 & 144.32 & $43.5-86.2$ & 4 \\
\hline & 0.4 & 203.40 & 249.42 & 200.95 & 194.96 & $95-149.4$ & 4 \\
\hline
\end{tabular}

Range of increment \% within the same concentration over control.

No. of superior extracts, on the base of the desirable significant effect.

Physical Pod traits:

Increase in pod traits such as pod length, number of seeds/pod and average pod weight under cold temperature conditions was obtained as a result of most different treatments in this study. Reversing the abovementioned traits, the $0.3 \%$ micro-algae extracts were more effective than the same concentration of macro-algae treatments (without any significant within the same concentrate) in reflect the highest values for most pod traits, however, $0.3 \%$ Anbaena oryzae extract showed a maximum increment in pod length and number of seeds per pod by $11.0 \%$ and $33.3 \%$, respectively (Table 6) over the corresponding untreated plants (control) followed by $0.3 \%$ Nostoc muscorum in both traits. In mean time, both $0.4 \%$ Nostoc muscorum and $0.3 \%$ Anabaena oryzae extracts exhibited a high significant increment in pod weight by $51.1 \%$ and $44.7 \%$, respectively followed by both $0.4 \%$ Anabaena oryzae and 0.3 Nostoc muscorum by $42.4 \%$ and $31.0 \%$, respectively. On the other hand, $0.4 \%$ conc. of Caulerpa racemosa extract exhibited slightly decrease effect in the three pod characters. The extent of variation for pod length was from $-9.3 \%-11.0 \%$ for all types and concentrations of extracts (Table 6); with non-extracts showing any significant differences with control. The responses expression for number of seeds per plant varied with values ranging from $-8.3 \%-33.3 \%$ for all types of extracts. Significant increment up to $51.1 \%$ over control was recorded for average pod weight. Four blue-green algae (cyanobacteria) extracts exhibited significantly increasing over distilled water control for pod weight.

Yield traits:

Results showed that, significant increase in both yield/plant and yield/feddan as well as significantly equal values of some cases in number of pods trait; under cold temperature conditions; was obtained as a result of most different treatments in this study. However, the $0.4 \%$ concentrate of all studied extracts were more effective than the $0.3 \%$ one within the same alga in reflect the highest values for all yield traits. With regard number of Pods (Table 6), treated the plants with the different concentrations of algae species showed that $0.4 \%$ concentrate for each of Cystoseira myrica, Caulerpa racemosa and Nostoc muscorum (blue greenalgae) extracts (without significant differences between them) recorded a maximum increment in number of pods/plant by $57.7 \%, 50.0 \%$ and $46.2 \%$ over control followed by $0.3 \%$ conc. of both Cystoseira myrica and Nostoc muscorum as well as $0.4 \%$ Anbaena oryzae (without significant differences between them) by $34.6 \%, 26.9 \%$ and $25.0 \%$ increment, respectively. On the other hand, $0.3 \%$ conc. of Caulerpa racemosa extract exhibited slightly increase effect with about $15.4 \%$. Significant positive increment for pod number per plant up to $57.7 \%$ over control was recorded. Out of all studied extracts, 6 over control showed 
Citation: Noha G. Abu Setta et al., Potentiality of algae extracts in alleviating stresses effect on common bean under upper Egypt conditions. Advances in Environmental Biology.12(12): 28-37. DOI:10.22587/aeb.2018.12.12.6

desirable significant increases for this trait. On the other hand, Treated of the plants with the different concentrations of algae species for yield/plant showed that, $0.4 \%$ Nostoc muscorum, each of $0.4 \%$ Anabaena oryzae, $0.4 \%$ Caulerpa racemosa and $0.4 \%$ Cystoseira myrica (without significant differences between them) extracts exhibited a maximum increment in yield of pods/plant by $149.4 \%, 103.4 \%, 101.0 \%$ and $95.0 \%$ over control followed by, $0.3 \%$ Nostoc muscorum, 0.3 \% Anabaena oryzae and $0.3 \%$ of both Cystoseira myrica and Caulerpa racemosa (without significant differences between them) by $86.2 \%, 56.9 \%, 44.3 \%$ and $43.5 \%$ increment, respectively. Increment of total yield per plant expressed as the percentage deviation of mean performance (treated plants) from control are presented in Table 6. Estimates increment varied between 43.5\% - 149.4\%. All eight extracts showed significant positive effect.

Over all open field trials, all foliar applications significantly increased most plant growth, photosynthetic pigments, pods and yield characteristics compared with the corresponding control of either cold, nitrogen deficiency or drought stress. However, it noticed that the high concentrations $(0.4 \%)$ of all studied extracts gave a significantly highest enhancement than, or equal to, lowest $(0.3 \%)$ concentration in most common bean traits under all studied conditions. The results reveal that the $0.4 \%$ of both Nostoc muscorum and Anabaena oryzae extracts can be considered the best extracts among the 8 algae foliar spray treatments evaluated for all experimental conditions in the present work, i.e., cold, nitrogen deficiency or drought stresses. As shown in Table (4), Both Caulerpa racemosa and Nostoc muscorum extracts at $0.4 \%$ concentrations have the significant increment effects in plant height $(24.8 \% \& 17.1 \%)$, number of leaves $(9.8 \& 4.1 \%)$, number of branches $(81.1 \& 62.2 \%)$ and leaf area $(20.3 \& 21.6 \%)$ over the corresponding untreated plants under cold stressful condition alone. Both $0.4 \%$ Anabaena and 0.3 $\%$ Nostoc extracts concentrations have the significant increment effects (Table 7) in plant height (45.4\% \& $14.4 \%$ ), number of leaves $(2.14 \& 21.4 \%)$, number of branches $(122.2 \% \& 133.3 \%)$ and leaf area $(15.69 \& 68.5 \%)$ over the corresponding untreated plants under combined of cold and nitrogen stressful condition. While, $0.4 \%$ Cystoseira myrica (cold alone, Table 5) extract showed a maximum increment in all the traits of pigments content, i.e., chlorophyll a, chlorophyll b and total chlorophyll by $16.3 \%, 21.7 \%$ and $16.7 \%$, respectively over the corresponding untreated plants (control) under cold stress alone.

Table 7: Relative changes in vegetative traits (\%) of Phaseolus vulgaris exposed to the applied treatments of algae extracts under cold and nitrogen deficient (50\% N) combined stress.

\begin{tabular}{|c|c|c|c|c|c|}
\hline \multicolumn{2}{|c|}{ Treatments } & \multicolumn{2}{|c|}{ Micro algae extraction } & \multicolumn{2}{|c|}{ Macro algae extraction } \\
\hline \multirow[t]{2}{*}{ Traits } & Conc. & \multirow[t]{2}{*}{ Anabaena oryzae } & \multirow[t]{2}{*}{ Nostoc muscorum } & \multirow[t]{2}{*}{ Caulerpa racemosa } & \multirow[t]{2}{*}{ Cystoseira myrica } \\
\hline & $\%$ & & & & \\
\hline \multirow[t]{3}{*}{ plant height } & 0 & $100 \%$ & $100 \%$ & $100 \%$ & $100 \%$ \\
\hline & 0.3 & 105.26 & 114.55 & 143.34 & 126.01 \\
\hline & 0.4 & 145.51 & 121.67 & 136.22 & 134.06 \\
\hline \multirow[t]{3}{*}{ No of leaves } & 0 & $100 \%$ & $100 \%$ & $100 \%$ & $100 \%$ \\
\hline & 0.3 & 64.29 & 121.43 & 80.71 & 112.14 \\
\hline & 0.4 & 102.14 & 109.29 & 83.57 & 107.14 \\
\hline \multirow[t]{3}{*}{ No of branches } & 0 & $100 \%$ & $100 \%$ & $100 \%$ & $100 \%$ \\
\hline & 0.3 & 148.0 & 233.3 & 211.1 & 211.1 \\
\hline & 0.4 & 222.20 & 185.2 & 148.1 & 185.2 \\
\hline \multirow{3}{*}{ Leaf area } & 0 & $100 \%$ & $100 \%$ & $100 \%$ & $100 \%$ \\
\hline & 0.3 & 114.25 & 168.53 & 86.79 & 107.54 \\
\hline & 0.4 & 115.69 & 94.93 & 99.73 & 175.74 \\
\hline
\end{tabular}

Comparing the performance of the extracts on the basis of total yield per plant (g/plant) under full recommended levels of both nitrogen and irrigation (cold stress) and highest desirable response for yield as well as the effects of extracts on other traits (in all conditions) was done to all extract concentrations (Table 8).Six out of the eight studied extracts were classified as a good affect source in desirable trend on yield. Five out of these 6 extracts exhibited significant positive effects for plant height, leaf area and number of pods per plant. Three out of these five extracts namely: $(0.4 \%$ Nostoc muscorum), $(0.4 \%$ Caulerpa racemosa) and $(0.3 \%$ Nostoc muscorum) exhibited significant desirable positive effect for number of branches. Two out of these three extracts $(0.3 \%$ and $0.4 \%$ Nostoc muscorum) along with the two best extracts $(0.3 \%$ \& 0.4 Anabaena oryzae $)$ recorded the highest significant desirable positive increment for pod weight and yield/plant under each of cold condition, nitrogen deficiency and drought stress (Table 8$)$ as well as the superiority of (0.4\% Cystoseira myrica) extract for positive effect of both chlorophyll-b and total chlorophyll contents, indicating the possibility of combine both high yield and good quality characters under various environmental conditions. The five extracts, which exhibited significant positive effect for yield/plant, were also combined significant/highly significant desirable negative or positive (due to the point of view) effects for three or more important studied characters particularly vegetative growth, pigments content, pod traits....etc. However, no effect of the undesirable deficiency appeared in any studied traits except with the number of leaves by using low concentrations of both Anabaena oryzae and Nostoc muscorum as well as the high concentrate of Anabaena oryzae, which may be due to the causes of overlapping stresses or defect in recommended dose of nitrogen fertilizer application. Again, these results reveal that the $0.4 \%$ of both Nostoc muscorum and Anabaena oryzae extracts can be considered the best extracts among the 8 algal extracts foliar spray treatments evaluated for all experimental conditions in the present work, i.e., cold, nitrogen deficiency or drought stresses. Moreover, both the (0.4\% Caulerpa racemosa) and (0.4\% Cystosiera myrica) extracts showed high positive responses only, in case of both cold and drought double stresses, while all other 4 best extracts $(0.3 \%$ Anabaena oryzae, $0.3 \%$ Nostoc muscorum, $0.3 \%$ Caulerpa racemosa and 0.3 $\%$ Cystosiera myrica) affected relatively on some traits. Our results reveal that the abovementioned algae extract treatments might be of prime importance in organic agricultural program and for traditional agricultural procedures for high yield and/or some of its important components. Discussed this study showed that common bean production is a profitable, healthy and safe enterprise when the suitable type of our algae extracts is used with saving half (50\%) recommended nitrogen rates or alleviation of water deficit. That's why applied study was done, and results are very promising in which these extracts can be used in common bean cultivations under the cold stress alone or combined with either nitrogen deficiency or drought stresses and similar environments. [39] and [40] observed that cold stress induced several morphological symptoms such as necrosis, desiccation, tissue breakdown and wilting, reduced leaf expansion and growth retardation in different plant species such as Common bean, Cole crops and Maiz. Because Common bean is a cooling-sensitive crop [41], environmental stresses such as low temperature during early stages of development can be detrimental to subsequent crop establishment and productivity [42]. Therefore, it is important to devise biochemical, and physiological means to protect bean from such environmental adversities [43] and to minimize losses due to stress. Among these techniques, applying chemicals or growth regulators which help to inhibit abnormal physiological processes within the plant. Therefore, we believe that foliar spray of algae extracts (in the present work) may be alter the antioxidant capacity of plants and detoxify superoxide radicals thereby providing protection against oxidative damage and induces stress tolerance [41] and then, the deleterious effect of stress is mitigated with different extents using these treatments and the beneficial effect of these treatments is manifested in terms of enhanced growth and photosynthesis as showed in our results. Many views on the nature of the algae extracts substances are among researchers, some described as hormones [44] and others described as vitamins [45] or amino acids [46]. Also, there are other studies described as it excreted IAA and amino acids [47]. Thus, algae have shown tremendous potential in terms of their plant growth promoting activity. [48], [49] and [50] reported that biofertilization with a mixture of $\mathrm{N}$ fixing cyanobacteria decreased the use of $\mathrm{N}$ fertilizer by $50 \%$, to get the same yield and quality compared with the full dose of chemical fertilize. Finally, we can suggested that biostimulants algae extracts can promote plant growth may be due to activate root cells at the same time stimulate biosynthesis of endogenous cytokinins from roots; enhancing leaf water status, some plant nutrients uptake, shoot growth and root pull strength; altering hormonal balances and favor cytokinins and auxins production [51]; enhancement of antioxidant enzymes (SOD, GR, ASP) for protection against adverse environmental conditions [41] and protection of plant cells from lipid peroxidation and in activation of enzymes that occur under stress [52].Many researchers recorded down regulation of IAA due to cooling stress. [53] stated that "the intracellular auxin transport, and the auxin gradient, plays a major role in controlling auxin and other hormonal cross talks that regulate plant growth and development". Generally, our results proved that all used algae excrete plant growth promoting substances such as indole acetic acid (IAA), Gibberellic acid $\left(\mathrm{GA}_{3}\right)$ with excellence for Cystoseira myrica in $\mathrm{GA}_{3}$, while cyanobacteria were 
Citation: Noha G. Abu Setta et al., Potentiality of algae extracts in alleviating stresses effect on common bean under upper Egypt conditions. Advances in Environmental Biology.12(12): 28-37. DOI:10.22587/aeb.2018.12.12.6

superior in indole acetic acid (IAA) that led to an increasing in common bean plant traits as a result of foliar spraying with these extracts that increment most studied bean characteristics over the control beside decreasing of cold stressful effects during planting season. In this context, foliar spraying of algae extracts (in which contain a good amount of these hormones (Fig. 8), in corresponding concentrates may be serves as an important cofactor in the biosynthesis and signaling of many phytohormones, gibberellic acid and abscisic acid under stressful conditions. These confirm that algalization spray by most studied algae extracts made as growth regulators considerably alleviate all stressful conditions. Therefore, we find that algae in our study have additional useful roles, biological activity that helps to overcome various stresses.

Table 8: The best extracts chosen on the basis of mean yield along with desirable significant effect for other traits comparing with control.

\begin{tabular}{|c|c|c|c|c|c|c|c|c|}
\hline \multirow[t]{4}{*}{ Alga Extract } & \multirow{4}{*}{$\begin{array}{c}\text { Mean } \\
\text { yield/plant } \\
\text { value } \\
(\mathrm{g}) \\
\\
\text { Cold stress }\end{array}$} & \multicolumn{4}{|c|}{ Increment over distilled water } & \multirow{2}{*}{\multicolumn{3}{|c|}{$\begin{array}{l}\text { Desirable significant effect for other } \\
\text { traits due to compare with control: }\end{array}$}} \\
\hline & & \multicolumn{3}{|c|}{$\begin{array}{l}\% \text { yield/plant (over corresponding control) under } \\
\text { cold stress with: }\end{array}$} & \multirow{3}{*}{$\begin{array}{l}\text { Range \% of traits } \\
\text { responses }\end{array}$} & & & \\
\hline & & & & & & \multirow{2}{*}{$\begin{array}{c}\text { Sign. } \\
\text { increased } \\
\text { traits }\end{array}$} & \multirow{2}{*}{$\begin{array}{c}\text { Sign. } \\
\text { decreased } \\
\text { traits }\end{array}$} & \multirow[t]{2}{*}{ Sign.Equal } \\
\hline & & $\begin{array}{l}\text { Recommended } \\
\text { nitrogen }\end{array}$ & $\begin{array}{l}\text { Nitrogen } \\
\text { deficiency }\end{array}$ & Drought stress & & & & \\
\hline Nos $0.4 \%$ & 122.1 & $149.4 \%$ & $101.2 \%$ & $120.9 \%$ & $8.2 \%-149.4 \%$ & $\mathrm{a}, \mathrm{c}, \mathrm{d}, \mathrm{k}$ & - & $\mathrm{R}$ \\
\hline Ana 0.4\% & 99.6 & $103.4 \%$ & $81.3 \%$ & $146.1 \%$ & $8.2 \%-103.4 \%$ & $\mathrm{a}, \mathrm{d}, \mathrm{j}, \mathrm{k}$ & $\mathrm{b}$ & $\mathrm{R}$ except $\mathrm{b}$ \\
\hline Саи $0.4 \%$ & 98.4 & $101.0 \%$ & $17.0 \%$ & $120.0 \%$ & $9.8 \%-101 \%$ & $\mathrm{a}, \mathrm{c}, \mathrm{d}, \mathrm{k}$ & - & $\mathrm{R}$ \\
\hline Cys $0.4 \%$ & 95.5 & $95.0 \%$ & $11.9 \%$ & $75.4 \%$ & $2.3 \%-95 \%$ & $\mathrm{a}, \mathrm{d}, \mathrm{f}, \mathrm{g}, \mathrm{k}$ & - & $\mathrm{R}$ \\
\hline Nos $0.3 \%$ & 91.2 & $86.2 \%$ & $82.2 \%$ & $83.8 \%$ & $6.8 \%-86.2$ & $\mathrm{a}, \mathrm{c}, \mathrm{d}, \mathrm{j}, \mathrm{k}$ & $\mathrm{b}$ & $\mathrm{R}$ except $\mathrm{b}$ \\
\hline Ana $0.3 \%$ & 76.8 & $56.9 \%$ & $82.5 \%$ & $72.7 \%$ & $6 \%-56.9 \%$ & $a, d, j$ & $\mathrm{~b}$ & $\mathrm{R}$ except $\mathrm{b}$ \\
\hline Cys $0.3 \%$ & 70.7 & $44.3 \%$ & $21.3 \%$ & $36.0 \%$ & $4.2 \%-44.3 \%$ & $\mathrm{a}, \mathrm{d}, \mathrm{k}$ & - & $\mathrm{R}$ \\
\hline Caи $0.3 \%$ & 70.3 & $43.5 \%$ & $12.3 \%$ & $62.0 \%$ & $5.1 \%-54.1 \%$ & $\mathrm{a}, \mathrm{c}, \mathrm{d}$ & - & $\mathrm{R}$ \\
\hline
\end{tabular}

a: plant height, b: leaves /plant, c: branches/plant, d: leaf area, e: chl-a, f: chl-b, g: total chlorophyll, $h:$ pod length, $i:$ seeds number/pod, $j:$ pod weight and $k$ : pods number/plant $R$ : the rest of the studied traits Nos: Nostoc muscorum Ana: Anabaena oryzae Cau: Caulerpa racemosa Cys: Cystoseira myrica

\section{CONCLUSION}

Algae extracts can provide a suitable supplement to the chemical fertilizers and 'organic farming' can become a reality in the future. There is a definite need to deploy these bio fertilizers, in combination with organic composts and minimal doses of chemicals fertilizers to harvest "cleaner" and healthy crops, secure food production, human health, protect the environment, and save scarce natural resources. Whatever the point of view, the algae in our study demonstrate their effectiveness in promoting plant growth under double stress conditions (nitrogen deficiency or drought stress with cold weather). Again, our results reveal that the abovementioned algae extract treatments might be of prime importance in organic agricultural program and for traditional agricultural procedures for high yield and/or some of its important components.

\section{CONFLICT OF INTEREST}

The authors declare that there are no conflicts of interest.

\section{ACKNOWLEDGEMENT}

Great thanks is to the chairman and staff members of Horticulture Res. Inst., Agric. Res. Center, Giza (specially Dr. Kareem M. K. Eltobgy), for providing necessary chemical analyses methods facilities during this study.

\section{AUTHOR CONTRIBUTIONS}

H.S., A.A.E. and H.R.G. conceived the original idea. N.G.A., H.S., A.A.E. carried out the experiments and analyzed the data. H.S., A.A.E. discussed the results and contributed to the final manuscript. H.R.G. revised the manuscript.

\section{REFERENCES}

1-Bhakuni, D.S. and D.S. Rawat (2005). Bioactive Marine Natural Products. Anamaya Publishers, New Delhi., 382pp.

2-Petersen, A.C. (1985). Effects of water stress on (Phaseolus vulgaris L.) and (Phaseolus latifolius), Freeman. Ph.D. thesis, University of Minnesota $213 \mathrm{p}$.

3-Cabriales, P.J.J. and J.Z. Castellanos (1993). Effects of water stress on N2 fixation and grain yield of Phaseolus vulgaris L. Plant and soil, 152: 151-155.

4- Kabahuma, M. K. (2013). Enhancing biological nitrogen fixation in common bean (Phaseolus vulgaris L.) A thesis submitted to the graduate faculty in partial fulfillment of the requirement for the degree of Master of Science. Iowa State University. pp160.

5-IPCC, (Intergovernmental Panel on Climate Change) (2007). Summary for policymakers. In: Parry M.L., O.F. Canziani, J.P. Palutikot, P.J. Van Der Linden and C.E. Hanson (eds) Climate change 2007: Impacts, adaptation and vulnerability. Contribution of Working Group II to the Fourth Assessment Report of the Intergovernmental Panel on Climate Change. Cambridge University Press, Cambridge, UK.

6- Khan W, U. P. Rayirath, S. Subramanian, M. N. Jithesh, P. Rayorath, D. M. Hodges, A. T. Critchley, J. S. Craigie, J. Norrie and B Prithiviraj (2009). Seaweed extracts as biostimulants of plant growth and development. J. Plant Growth Regulation 28:386-399.

7-Latique, S., H. Chernane, M. Mansori and M. El Kaoua (2013) Seaweed liquid fertilizer effect on physiological and biochemical parameters of bean plant (Phaesolus vulgaris variety paulista) under hydroponic system. European Scientific Journal vol.9 (30): 1857 - 7881.

8-Hankins, S.D. and H.P. Hockey (1990). The effect of a liquid seaweed extract from Ascophyllum nodosum (Fucales, Phaeophyta) on the two spotted red spider mite Tetranychusurticae. Hydrobiologia, 204(205):555-559.

9-Blunden, G. (1991). Agricultural uses of seaweeds and seaweed extracts. In: Guiry MD, Blunden G (eds) Seaweed resources in Europe: uses and potential. Wiley, Chicester, pp 65-81.

10-Norrie, J. and J.P. Keathley (2006). Benefits of Ascophyllum nodosum marine-plant extract applications to 'Thompson seedless' grape production. (Proceedings of the $X^{\text {th }}$ International Symposium on Plant Bioregulators in Fruit Production, 2005). ActaHortic 727:243-247.

11-Duan, B., Y. Yang, Y. Lu, H. Korpelainen, F. Berninger and C. Li (2007). Interactions between drought stress, ABA and genotypes in Piceaasperata. Jour. Experimental Botany, 58: 3025-3036.

12-Praba, M.L., J.E. Cairns, R.C. Babu and H.R. Lafitte (2009). Identification of physiological traits underlying cultivar differences in drought tolerance in rice and wheat. Jour.Agron.\& Crop Science 195:30-46.

13-Kasim W.A., E.A.M. Hamada, N.G. Shams El-Din and S.K. Eskander, (2015). Influence of seaweed extracts on the growth, some metabolic activities and yield of wheat grown under drought stress Inter. J. Agron. \& Agri. Res. 7(2): 173-189.

14-Waterbury, J. B. and R. Y. Stanier (1981). Isolation and growth of cyanobacteria from marine and hypersaline environments. The Prokaryotes, 7: $221-223$.

15-Strickland, J. and T. Parsons (1972). A practical handbook of seawater anysis. Fish Res Board Can Bull; 167:310. 
Citation: Noha G. Abu Setta et al., Potentiality of algae extracts in alleviating stresses effect on common bean under upper Egypt conditions. Advances in Environmental Biology.12(12): 28-37. DOI:10.22587/aeb.2018.12.12.6

16-Marker, A. and S. Jinks (1982). The spectrophotometric analysis of chlorophyll $a$ and pheopigments in acetone, ethanol and methanol. In: Rai H, Marker A, editors. The measurement of photosynthetic pigments in freshwaters and standardization of methods. Arch Hydrobiol Beih Ergebn Limnol; 16:3-17.

17-Bag, G.C., P. Grihanjali Devi and T.H. Bhaigyabati (2015). Assessment of Total Flavonoid Content and Antioxidant Activity of Methanolic Rhizome Extract of Three Hedychium Species of Manipur Valley Int. J. Pharm. Sci. Rev. Res., 30(1):28-154-159.

18-Antolovich, M, P.D. Prenzler, E. Patsalides, S. McDonald and K. Robards (2002). Methods for testing antioxidant activity. Analyst. 127(1):183-98.

19-Prieto, P., M., Pineda and M., Aguilar (1999). Spectrophotometric quantitation of antioxidant capacity through the formation of a phosphomolybdenum complex: specific application to the determination of vitamin E. Analytical Biochemistry, 269(2), 337-341.

20-Partridge, S.M. (1949). Filter paper partition chromatography of sugars. J. of Bioch. 42:138-140.

21-Lowry, O.H., N.J. Rosebrough, A.L. Farr and R.J. Randall (1951). Protein measurement with the Folin phenol reagent. J. boil. Chem., 193(1), pp.265-275.

22-Sadasivam, S. and A. Manickam (1996). Biochemical Methods. New Age International (P) Limited, Published, London,, 23.

23-Bergman, I. and R. Loxley (1970). New spectrophotometric method for the determination of proline in tissue hydrolyzates. Anal Chem., $42: 702-706$.

24-Allen, S.E., H.M. Grinshaw, J.A. Parkinson and C. Quarmby. (1974). Chemical analysis of ecological materials. Blackwell Scientific Publications, Oxford, p 565.

25-Kowolczyck, M. and G. Sandberg. (2001). Quantitative analysis of indole-3-acetic acid metabolites in Arabidopsis. Plant Physiol. 127:1845-1853.

26- Wettestein, D. (1957). Chlorophyll - Lethale und der Submikros kopische Formwechsel der Plastiden. Exptl. Cell Reso., 12: 427- 433.

27-Gomez, K.A. and A.A. Gomez (1984). DES and SA on quantitative traits of cowpea Statistical Procedures for Agricultural (Vigna unguiculata Walp.) in M1 generation. Crop Research. John Wiley and Sons, $2^{\text {nd }}$ Ed., New York, Research (Hisar), 37: 239-241.

28-Silva, F.A.S. and C.A.V. Azevedo (2016a). Comparison of means of agricultural experimentation data through different tests using the software Assistat. Afr. J. Agric. Res. 11(37), pp. 3527-3531.

29-Silva, F.A.S. and C.A.V. Azevedo (2016 b). The Assistant Software Version 7.7 and its use in the analysis of experimental data. Afr. J. Agric. Res. Vol. 11(39), pp. 3733-3740.

30-Viswanathan, S., C. Ebciba, R. Santhiya and S. Nallamuthu (2014). Phy-tochemical screening and In vitro antibacterial, antioxidant and anticancer activity of Amphiro Fragilissima, Int. J. Innov. Res. Sci.: Eng. Technol. 3: 2319-8753.

31-Soad, M. Mohy El-Din and Amani M.D. El-Ahwany (2016). Bioactivity and phytochemical constituents of marine red seaweeds (Janiarubens, Corallinamediterraneaand Pterocladiacapillacea). Journal of Taibah University for Science 10 471-484.

32-Burtin, P. (2003). "Nutritional value of sea seaweeds," Electronic Journal of Environmental, Agricultural and Food Chemistry, 2: 498-503.

33- Duan X.J., W.W. Zhang, W.X.M. Li and B.G. Wang (2006) Evaluation of antioxidant property of extract and fraction obtained from red alga Polysiphonie urcelata, Food Chem. 95: 1022-1037.

34-Kahkonen, M., P. Hopia, Hj. Vuorela, H. Rauha and J.P. Kujala (1999). Antioxidant activity of plant extract containing phenolic com-pounds, J. Agric. Food Chem. 47 349-362.

35-L'opez, A., M. Rico, A. Rivero and M. Su'arez de Tangil (2011). "The effects of solvents on the phenolic contents and antioxidant activity of Stypocaulonscoparium algae extracts," Food Chemistry 125 (3): 1104-1109.

36-Tierney, M.S., T. J. Smyth, M. Hayes, A. Soler-Vila, A. K. Croft, and N. Brunton (2013), "Influence of pressurised liquid extraction and solid-liquid extraction methods on the phenolic content and antioxidant activities of Irish macroalgae," International Journal of Food Science and Technology, vol. 48, no. 4, pp. 860-869.

37-Li, F., R.Vallabhaneni, J. Yu, T. Rocheford and ET Wurtzel (2008) The maize phytoene synthase gene family: overlapping roles for carotenogenesis in endosperm, photomorphogenesis, and thermal stress tolerance. Plant Physiol147 (3): 1334-1346.

38-Berfad, M. A. (2009). Study of some Biological Effects for the Extracts of the Alga Cystoseria Compressa. M.Sc. Thesis Al Khums Elmergib University Libya.

39-Rymen, B., F. Fiorani, F. Kartal, K. Vandepoele, D. Inze and G. T. S. Beemster (2007). Cold nights impair leaf growth and cell cycle progression in maize through transcriptional changes of cell cycle genes. Plant Physiol. 143:1429-1438.

40-Nahar, K., M. Hasanuzzaman, R.R. Majumder (2009). Effect of low temperature stress in transplanted Aman Rice Varieties mediated by different transplanting dates. Acad J Plant Sci 2: 132-138.

41-Eman, Y.M. Hamed (2014). Physiological Impact of Chilling Injury on Bean (Phaseolus vulgaris L.) Plant. M. Sc., Thesis Fac. Science Cairo University, Egypt. Pp. 239.

42-Greaves, J.A. (1996). Improving suboptimal temperature tolerance in maize the search for variation. Journal of Experimental Botany, 47, 307-323.

43-Purvis, A.C., Shewfelt R.L. (1993). Does alternative pathway ameliorate chilling injury in sensitive plant tissues. Plant Physiology 88, 712-718.

44-Ali, Laila K. M. and Soha S. M. Mustafa (2009). Evaluation of potassium humate and Spirulina platensis as bioorganic fertilizer for sesame plants grown under salinity stress. Egypt. J. Agric. Res., 87(1): 369-388.

45-Misra, S. and B. D. Kaushik (1989). Growth promoting substances of cyanobacteria. I. Vitamins and their influence on rice plant. Proc. Indian Sci. Acad. B 55 295-300.

46-Watanabe I. and P. A. Roger (1984). Nitrogen fixation in wetland rice fields, in: N.S. Subba Rao (Ed.), Current Developments in Biological Nitrogen Fixation, Oxford IBH, New Delhi, pp. 237-276.

47-Karthikeyan, N., R. Prasanna, L. Nain and B. D. Kaushik (2007). Evaluating the potential of plant growth promoting cyanobacteria as inoculants for wheat. Europ. J. of Soil Biology 43: 23-30.

48-Amal, Z. Hegazi, Soha S. M. Mostafa and H. M. I. Ahmed (2010). Influence of Different Cyanobacterial Application Methods On Growth And Seed Production Of Common Bean Under Various Levels Of Mineral Nitrogen Fertilization. Nature and Science 8(11):183-194.

49-Uysal, O., F.O. Uysal and K. Ekinci (2015). Evaluation of microalgae as microbial fertilizer. Eur. J. Sustain. Dev. 4: 77-82.

50-Vasileva I., J. Ivanova and M. Paunov (2016). Urea from waste waters - perspective nitrogen and carbon source for green algae Scenedesmus sp. cultivation. Ecol. Safe. 10: 311-319.

51-Schmidt, R.E. (2005). Bio stimulants function in turf grass nutrition. Ph.D. emeritus virginia tech.

52-Zewail, R.M.Y. (2014). Effect of seaweed extract and amino acids on growth and productivity and some of bio-constituents and some of common bean (Phaseolus vulgaris L.) Plants. J. Plant Production, Mansoura Univ., Vol. 5 (8):1441 - 1453.

53-Rahman, A. (2013). Auxin: a regulator of cold stress response. Physiol. Plant 147: 28-35. 